\title{
Pengaruh Iklim Terhadap Produksi Tembakau Kabupaten Jember
}

\author{
The Impact of Climate on Tobacco Production in Jember Regency
}

\author{
Irma Harlianingtyas ${ }^{\# 1}$, Cherry Triwidiarto ${ }^{* 2}$, Satria Indra Kusuma ${ }^{\# 3}$ \\ \#Produksi Pertanian, Politeknik Negeri Jember, Jl Mastrip POBOX 164 Jember \\ ${ }^{1}$ irma@polije.ac.id (corresponding author) \\ ${ }^{3}$ satria.ik@polije.ac.id \\ *Produksi Pertanian, Politeknik Negeri Jember, Jl. Mastrip PO BOX 164 Jember \\ ${ }^{2}$ cherry_triwidiarto@polije.ac.id
}

\begin{abstract}
ABSTRAK
Tembakau (Nicotiana tabacum L.) merupakan salah satu penghasil devisa yang cukup tinggi dalam negara karena bea cukainya. Disamping itu, tembakau memberikan kontribusi yang cukup besar dalam sumber pendapatan petani dan penyediaan lapangan pekerja. Tanaman tembakau sangat rentan di pengaruhi oleh klimatologi dan geografi wilayah. Budidaya tembakau maupun industrinya merupakan komoditi yang sangat berpengaruh dalam perekonomian tidak hanya bagi Jawa Timur namun juga mencakup kegiatan perekonomian secara global. Tembakau mempunyai beberapa varietas meliputi tembakau Voor-Ogst yang di gunakan untuk bahan membuat rokok putih maupun rokok kretek dan tembakau Na-Oogst yaitu jenis tembakau yang di pakai untuk bahan dasar membuat cerutu maupun cigarillo, disamping tembakau hisap atau kunyah (chewing tobaco). Tembakau jenis Voor-Oogst merupakan tembakau dengan periode tanam pada akhir musim penghujan dan periode petikan pada musim kemarau. Sementara tembakau Na-Oogst adalah tembakau dengan periodesasi tanam pada akhir musim kemarau dan periode petik pada awal musim penghujan. Produktivitas tanaman tembakau kasturi dan tembakau Besuki Na-Oogst di Kabupaten Jember mengalami penurunan yang sebabkan oleh cuaca yang tidak menentu, tingginya curah hujan, abu vulkanik Gunung Raung dan minimnya penyediaan sarana produksi. Tanaman tembakau termasuk tanaman yang sensitif terhadap faktor lingkungan diantaranya yaitu faktor iklim, seperti curah hujan, kelembapan, dan temperatur. Kondisi iklim pada curah hujan, baik jumlah dan penyebarannya yang sangat beragam sehingga berpengaruh terhadap pertumbuhan, produksi dan mutu tembakau. Penelitian ini bertujuan untuk mengidentifikasi karakteristik, menganalisis hingga menetukan pemodelan pengaruh faktor iklim terhadap produktivitas tembakau di Kabupaten Jember. Data yang digunakan dalam penelitian ini merupakan data sekunder yang diperoleh dari database Badan Pusata Statistik Kabupaten Jember. Metode penelitian yang digunakan adalah analisis regresi linier berganda dengan faktor iklim, seperti curah hujan, jumlah hari hujan, suhu udara, kelembapan menjadi variabel independent dan produktsi tembakau Kabupaten Jember menjadi variabel dependen. Model matematis yang terbentuk dari analisis regresi diperoleh hasil sebagai berikut : $\mathrm{Y}=2456782,324+0,890 \mathrm{X} 1+$ 0,120 X2 -16.272,407 X3 - 49617,901 X4 + 32,779 X5 dengan besar koefisien determinasi 96,7\%. Secara parsial faktor yang berpengaruh terhadap produksi tembakau adalah curah hujan, kelembapan, dan luas lahan.
\end{abstract}

Keywords - Tembakau; produktivitas; regresi; Jember

\begin{abstract}
Tobacco (Nicotiana tabacum L.) is one of the highest foreign exchange earners in the country because of its customs duties. In addition, tobacco makes a significant contribution to the source of farmers' income and the provision of employment opportunities. Tobacco plants are very susceptible to being influenced by the climatology and geography of the region. Tobacco cultivation and its industry are commodities that are very influential in the economy, not only for East Java but also for global economic activities. Tobacco has several varieties including Voor-Ogst tobacco which is used for making white cigarettes and clove cigarettes and Na-Oogst tobacco, which is the type of tobacco used for making cigars and cigarillos, in addition to chewing tobacco.Voor-Oogst tobacco is tobacco with a planting period at the end of the rainy season and a picking period in the dry season. Meanwhile, $\mathrm{Na-Oogst}$ tobacco is tobacco with a planting period at the end of the dry season and a picking period at the beginning of the rainy season. The productivity of Kasturi tobacco and Besuki Na-Oogst tobacco in Jember Regency has decreased due to erratic weather, high rainfall, volcanic ash from Mount Raung and the lack of production facilities. Tobacco plants are plants that are sensitive to environmental factors including climatic factors, such as rainfall, humidity, and temperature. The climatic conditions of rainfall, both the amount and the
\end{abstract}

\section{OPEN ACCESS}

(C) 2021. Irma Harlianingtyas, Cherry Triwidiarto, Satria Indra Kusuma 
distribution are very diverse so that it affects the growth, production and quality of tobacco. This study aims to identify characteristics, analyze and determine the modeling of the influence of climate factors on tobacco productivity in Jember Regency. The data used in this study is secondary data obtained from the database of the Central Bureau of Statistics of Jember Regency. The research method used is multiple linear regression analysis with climatic factors, such as rainfall, number of rainy days, air temperature, humidity as the independent variables and tobacco production in Jember Regency as the dependent variable. The mathematical model formed from the regression analysis obtained the following results: $Y=2456782.324+0.890 X 1+0.120 X 2-16.272 .407$ X3 - 49617.901 X4 + 32.779 X5 with a coefficient of determination of 96.7\%. Partially the factors that influence tobacco production are rainfall, humidity, and land area.

Keywords-Tobacco; productivity; regression; Jember 


\section{Introduction}

Tembakau (Nicotiana tabacum L.) merupakan salah satu komoditas tanaman perkebunan yang memiliki peran penting di Indonesia. Berdasarkan data statistik ekspor tembakau cenderung meningkat, sedangkan impor tembakau mengalami penurunan. Hal tersebut membawa dampak positif bagi pemerintah serta petani tembakau untuk dapat meningkatkan produktivitas dan kualitas sehingga mampu bersaing dengan produsen luar negeri [1]. Tanaman tembakau sangat rentan di pengaruhi oleh wilayah tertentu, seperti memerlukan kondisi daerah yang secara klimatologi dan geografi cocok dengan jenis tembakau [2].

Tahun 2018 produsen terbesar tembakau di Indonesia sesuai dengan besaran luas areal budidayanya adalah Provinsi Jawa Timur, Nusa Tenggara Barat, Jawa Tengah, Jawa Barat dengan total kontribusi sebesar $94,76 \%$ terhadap total produksi tembakau Indonesia, sedangkan kontribusi terbesar adalah Provinsi Jawa Timur [3]. Budidaya tembakau maupun industrinya merupakan komoditi yang sangat berpengaruh dalam perekonomian tidak hanya bagi Jawa Timur namun juga mencakup kegiatan perekonomian secara global [4].

Tembakau mempunyai beberapa varietas meliputi tembakau Voor-Ogst yang di gunakan untuk bahan membuat rokok putih maupun rokok kretek dan tembakau Na-Oogst yaitu jenis tembakau yang di pakai untuk bahan dasar membuat cerutu maupun cigarillo, disamping tembakau hisap atau kunyah (chewing tobaco) [5]. Tembakau jenis Voor-Oogst merupakan tembakau dengan periode tanam pada akhir musim penghujan dan periode petikan pada musim kemarau. Sementara tembakau Na-Oogst adalah tembakau dengan periodesasi tanam pada akhir musim kemarau dan periode petik pada awal musim penghujan [6].

Produksi tanaman tembakau dengan jenis tembakau Besuki Na-Oogst di Kabupaten Jember mengalami penurunan yang sebabkan oleh cuaca yang tidak menentu, tingginya curah hujan, abu vulkanik Gunung Raung dan minimnya penyediaan sarana produksi [7]. Hasil produksi tembakau kasturi sempat mengalami penurunan sebesar $40 \%$ disebabkan oleh tanaman yang terkena serangan hama dan penyakit serta terkena dampak perubahan temperatur dan kelembaban [8]. Kondisi tersebut selaras dengan produktivitas tanaman tembakau kasturi dapat mengalami penurunan yang disebabkan oleh perubahan iklim. Efek dari perubahan iklim inilah yang diduga memiliki pengaruh terhadap produktivitas tembakau di Kabupaten Jember [2].

Tanaman tembakau termasuk tanaman yang sensitif terhadap faktor lingkungan diantaranya yaitu faktor iklim, seperti curah hujan, kelembapan, dan temperatur. Temperatur optimal untuk pertumbuhan tanaman tembakau adalah $27^{\circ} \mathrm{C}$ atau berkisar antara $22-33^{\circ} \mathrm{C}$ [9]. Sedangkan kelembaban optimal pertumbuhan tanaman berkisar antara 70\%-80\% [6]. Kondisi iklim pada curah hujan, baik jumlah dan penyebarannya yang sangat beragam sehingga berpengaruh terhadap pertumbuhan, produksi dan mutu tembakau [10].

Berdasarkan uraian sebelumnya penelitian ini bertujuan untuk mengidentifikasi karakteristik, menganalisis hingga menetukan pemodelan pengaruh faktor iklim terhadap produktivitas tembakau di Kabupaten Jember. Hal ini sangat penting dilakukan untuk menentukan rekomendasi serta kebijakan terhadap peningkatan produktivitas tembakau di Kabupaten Jember baik yang diproduksi oleh petani maupun oleh perusahaan.

\section{Method}

\subsection{Sumber Data}

Sumber data yang digunakan dalam penelitian ini adalah data sekunder yang diambil dari database Badan Pusat Statistik Kabupaten Jember dan Dinas Pertanian Kabupaten Jember yang meliputi data, curah hujan, hari hujan, suhu, kelembapan udara, produksi tembakau, luas lahan tembakau, dan produktivitas tanaman tembakau di Kabupaten Jember dari tahun 2008 hingga 2019.

\subsection{Variabel Penelitian}

Variabel penelitian yang digunakan terbagi menjadi dua, yaitu variabel bebas/independen dan variabel respn/terikat/dependen. Variabel bebas/independen terdiri dari curah hujan, hari 
hujan, kelembapan, suhu udara, produksi tembakau, dan luas lahan tembakau. Sedangkan variabel dependen adalah produktivitas tembakau.

Definisi variabel operasional tiap variabel :

2.2.1. Curah hujan (X1) merupakan ketinggian air hujan yang terkumpul dalam tempat yang datar, tidak menguap, tidak meresap, dan tidak mengalir. Curah hujan 1 (satu) milimeter artinya dalam luasan satu meter persegi pada tempat yang datar tertampung air setinggi satu milimeter atau tertampung air sebanyak satu liter.

2.2.2. Jumlah hari hujan (X2) adalah total hari yang turun hujan yang dihitung per tahun pada seluruh wilayah Kabupaten Jember.

2.2.3. Suhu Udara (X2) merupakan ukuran panas pada wilayah Kabupaten Jember dengan satuan derajat celcius.

2.2.4. Kelembapan udara (X3) adalah kandungan uap air yang ada di udara dalam lingkup wilayah Kabupaten Jember dengan satuan persen.

2.2.5. Produksi tembakau (X4) merupakan produksi total dari tembakau yang dihasilkan oleh petani maupun perusahaan tembakau yg terdapat di Kabupaten Jember dengan satuan kwintal.

2.2.6. Luas lahan tembakau (X5) adalah seluruh lahan yang digunakan untuk menanam tembakau baik milik petani maupun perusahaan dengan satuan hektar.

2.2.7. Produksi tembakau (Y) terbagi menjadi 2 yakni tembakau Voor-Oogst dan $\mathrm{Na}$ Oogst yang dihitung per tahun dengan satuan kwintal/hektar.

\subsection{Langkah Analisis}

Berikut adalah tahapan analisis dalam setiap tujuan penelitian.

\subsubsection{Tahapan 1 adalah menyajikan data secara deskriptif dengan menyajikan ke dalam grafik atau diagram dari setiap variabel independen}

2.3.2. Langkah selanjutnya melakukan uji korelasi terhadap variabel independen untuk mengetahui

multikolinearitas antar

ada/tidak

independen.

2.3.3. Jika terdeteksi ada korelasi, menandakan adanya multikolinearitas. Sehingga penanganannya menggunakan metode Principal Component Analysis (PCA) dengan bantuan software Minitab.

2.3.4. Selanjutnya menaksir parameter yang tidak bias hingga terbentuk model regresi antara variabel dependen dan variabel independen.

2.3.5. Menggunakan software IBM SPSS 21 variabel curah hujan, jumlah hari hujan, suhu, kelembapan, produksi, dan luas lahan diinputkan sebagai variabel independen, dan variabel produktivitas tembakau diinputkan sebagai variabel dependen.

2.3.6. Mengestimasi parameter koefisien regresi dengan signifikan 5\%. Artinya 95\% parameter yang diestimasi menggambarkan keadaan sebenarnya.

2.3.7. Melakukan uji kebaikan model regresi, dengan melihat besarnya F.hitung dibanding F.tabel statistik pada tabel ANOVA.

2.3.8. Melakukan uji parsial (uji T) untuk mengetahui pengaruh masing-masing variabel independen terhadap variabel dependen.

2.3.9. Mengidentifikasi signifikansi error, apakah sudah memenuhi asumsi distribusi normal berdistribusi mormal, identik dan independen.

2.3.10. Apabila sudah memenuhi asumsi, maka model yang diperoleh dapat digunakan. Tetapi apabila belum memenuhi asumsi, maka diberikan solusi menggunakan regresi bootsrap ataupun regresi gulud.

2.3.11. Membuat model regresi yang sesuai.

2.3.12. Membuat interpretasi dari model regresi. 2.3.13. Menarik kesimpulan dan rekomendasi.

\section{Discussion}

\subsection{Produksi Tembakau}






Figure 1. Produksi Tembakau Kabupaten Jember

Produksi tembakau di Kabupaten Jember dari tahun ke tahun mengalami fluktuasi, hal ini disebabkan banyak faktor yang mempengaruhi, baik faktor on farm maupun off farm. Faktor on farm dipengaruhi oleh proses budidaya sedangkan faktor off farm meliputi proses pengolahan, pemasaran, dan distribusinya. Proses budidaya tembakau erat kaitannya dengan faktor iklim, hal ini dikarenakan iklim berperan besar dalam pertumbuhan tanman tembakau.

\subsection{Faktor Iklim}

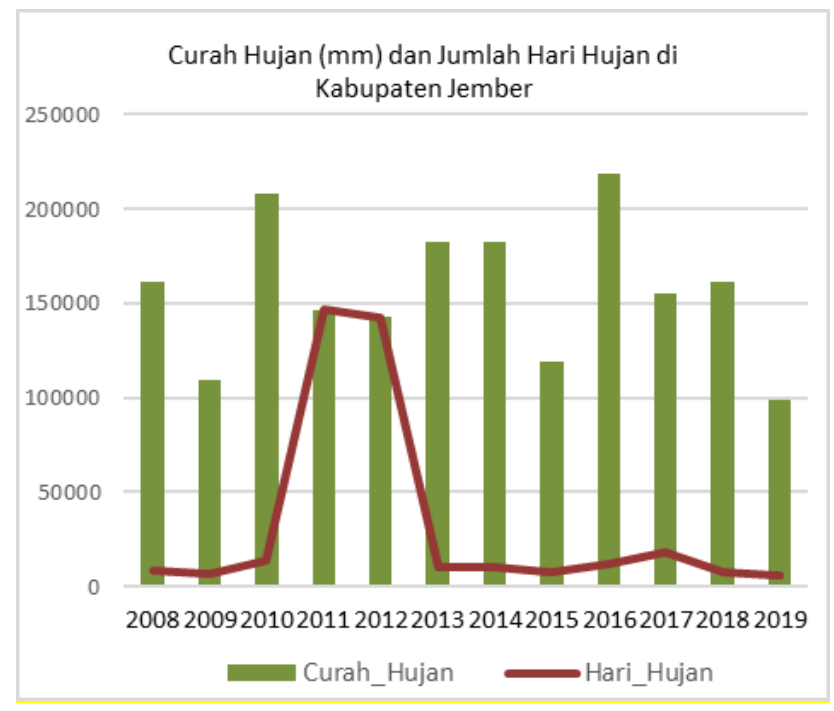

Figure 2. Curah hujan dan jumlah hari hujan

Curah hujan yang terjadi di Kabupaten Jember dari tahun 2008 hingga 2019 mengalami fluktuasi dan curah hujan terendah terjadi pada tahu 2019 dengan total curah hujan yang turun sebesar $98.888 \mathrm{~mm}$ per tahun dengan jumlah hari hujan yang terjadi pada tahun 2019 sebanyak 5708 hari. Curah hujan paling tinggi terjadi pada tahun 2016 dimana mencapai $218.399 \mathrm{~mm}$ dalam satu tahun.

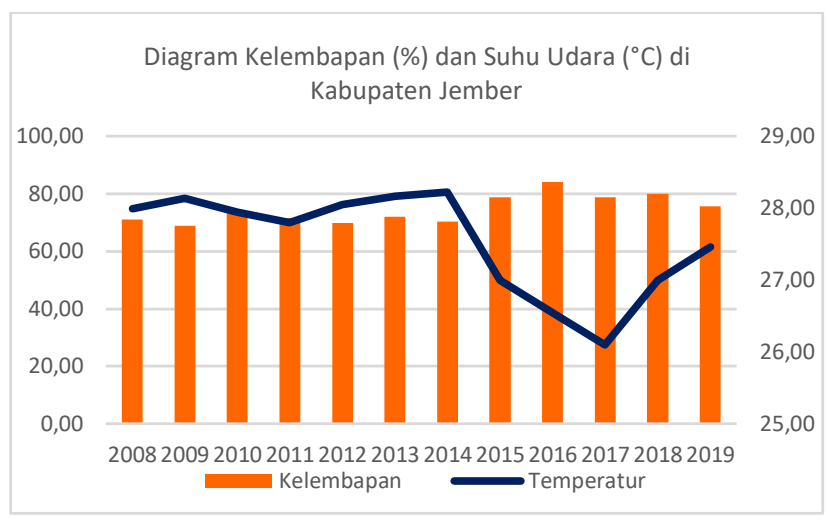

Figure 3. Kelembapan dan Suhu Udara

\subsection{Asumsi Klasik Regresi}

Data yang digunakan adalah data dari tahun 2008 hingga tahun 2019, setelah dilakukan deteksi outliar atau data pencilan ditemukan data pada tahun 2015 merupakan data outliar. Sehingga data tersebut dikeluarkan dan kemudian dilakukan analisis regresi. Hasil analisis regresi menggunakan metode Ordinary Least Square (OLS). Sedangkan asumsi yang harus dipenuhi dalam analisi regresi yakni residual berdistribusi normal, tidak terjadi multikolinearitas, tiak terjadi autokorelasi, dan tidak terjadi heteroskedastisitas. Oleh karena itu dilaukan deteksi pemeuhan asumsi sebelum dilakukan pemodelan. Hasil estimasi parameter dengan metode regresi dengan pendekatan OLS yang Best Linear Unbiased Estimator (BLUE) maka model persamaan regresi harus memenuhi asumsi klasik. Penyimpangan terhadap asumsi klasik menyebabkan terjadinya penyimpangan dari estimasi parameter baik besarnya konstanta maupun besarnya koefisien regresi.

\subsubsection{Uji Asumsi Regresi :}

Uji normalitas dilakukan untuk mengetahui residual yang diperoleh dari selisih y taksiran dengan y data asli mengikuti distribusi normal. Uji normalitas data menggunakan uji Kolmogorov smirnov dengan uji hipotesis sebagai berikut:

H0: Data berdistribusi noramal

H1: Data tidak berdistribusi normal

Level signifikasi: $5 \%(0,05)$

Hasil uji normalitas menunjukkan hasil sebagai berikut 


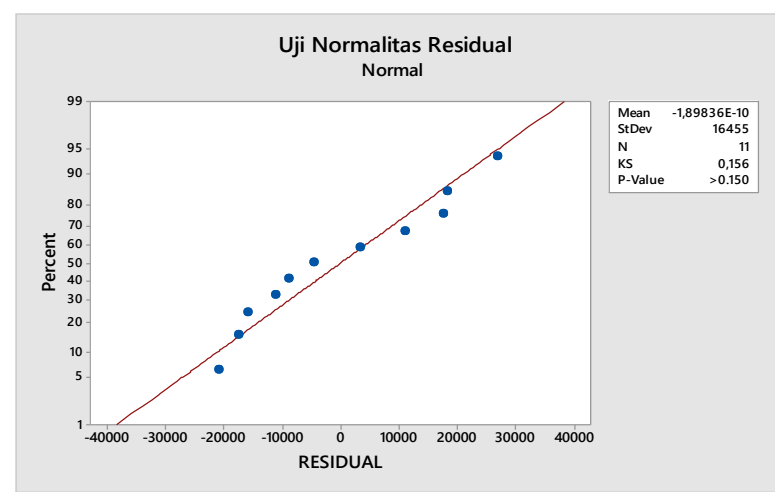

Figure 4. Uji Normalitas Residual

Hasil uji normalitas dapat dilihat dari besarnya p-value yang lebih dari 0,05 dan secara visual terlihat bahwa titik-titik residual mengikuti garis normalitas. Hal ini menunjukkan bahwa residual memenuhi asumsi berdistribusi normal.

\subsubsection{Uji Multikolinearitas:}

Asumsi kedua yang harus dipenuhi adalah tidak terjadi multikolinearitas antar variabel independent. Salah satu cara mendeteksi adanya multikolinearitas yakni dengan melihat Variance Inflation Factor (VIF), jika nilai VIF > 10 menunjukkan adanya multikolinearitas.

\begin{tabular}{|c|c|c|c|c|c|}
\hline \multicolumn{6}{|l|}{ Confticients } \\
\hline Term & $\cos t$ & SE chet & T-Val ue & P-Value & VIF \\
\hline Constant & 2453045 & 956967 & 2,56 & 0,050 & \\
\hline Curah Bujan 11 & 0,890 & 0,268 & 3,32 & 0,021 & 1,79 \\
\hline Hari Hulan 11 & 0,122 & $0,16 \mathrm{~B}$ & 0,73 & 0,501 & 1,54 \\
\hline Kolembapan 11 & -16269 & 4167 & $-3,90$ & 0,011 & 7,70 \\
\hline Temporatur 11 & -49482 & 25529 & $-1,94$ & 0,110 & 6,34 \\
\hline Luag Panon 11 & 32,66 & B, 03 & 4,07 & 0,010 & 2,77 \\
\hline
\end{tabular}

Figure 5. Deteksi Multikolinearitas

Berdasarkan gambar 4 diketahui bahwa nilai VIF pada semua variabel independen $<10$, sehingga dapat disimpulkan bahwa tidak terjadi multikolinearitas antar variabel independen pada model regresi.

\subsubsection{Uji Autokorelasi}

Asumsi yang ketiga yang harus dipenuhi adalah tidak ada autokorelasi antar residual, atau tidak adanya hubungan atau pengaruh dari residual data pertama ke residu data berikutnya. Mendeteksi adanya autokorelasi salah satunya adalah dengan uji Durbin Watson.

Hipotesis :

H0 $: \rho=0$ (tidak ada autokorelasi)
H1 $: \rho \neq 0$ (terjadi autokorelasi)

Daerah kritis :

Gagal tolak (terima) H0, jika dU $<$ DW $<(4-$ dU)

Durbin Watson Statistik:

$$
D W=\frac{\sum_{t-2}^{n}\left(e_{t}-e_{t-1}\right)}{\sum_{t=1}^{n} e_{t}^{2}}
$$

Hasil analisis:

Table 1. Uji Durbin Watson

\begin{tabular}{lll} 
R & R Square & Durbin-Watson \\
\hline 0.983 & 0.967 & 2.325 \\
\hline Diman
\end{tabular}

Dimana Durbin-Watson Statistik $=2.325$, sedangkan dari tabel Durbin Watson dengan jumlah variabel $6(\mathrm{p}=6)$, dan jumlah pengamatan $11(\mathrm{n}=11)$, maka diperoleh $\mathrm{dL}=$ 0,203 dan $\mathrm{dU}=3,005$. Karena nilai statistik Durbin Watson berada diantara dU dan dL sehingga disimpulkan bahwa hasil uji Durbin Watson tidak meyakinkan. Sehingga pengecekan autokorelasi menggunakan metode lain. Salah satu cara untuk mendeteksi adanya autokorelasi atar residual dapat dilihat dari plotting ACF.

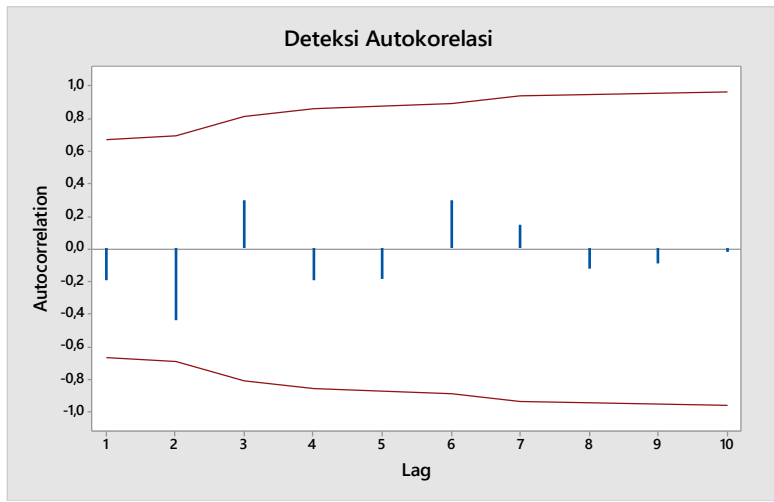

Figure 6. Deteksi Autokorelasi

Berdasarkan hasil gambar autokorelasi terlihat bahwa tidak terdapat lag yang melebihi garis merah, dimana garis merah adalah batas atas dan batas bawah dari garis autokorelasi. Sehingga dapat disimpulkan bahwa tidak terjadi autokorelasi antar residu dari data ke-t ke data berikutnya $\mathrm{t}-1$. 


\subsubsection{Uji Heteroskedastisitas:}

Salah satu cara untuk mendeteksi ada tidaknya heteroskedastisitas adalah dengan melakukan uji Glejser [21]. Uji Glejser mengusulkan untuk meregres nilai absolut residual terhadap variabel independen. Hasil probabilitas dikatakan signifikan jika nilai signifikansinya diatas tingkat kepercayaan $5 \%$. Jika nilai sig pada uji Glejser untuk setiap variabel bebas < 0,05 maka terjadi heteroskedastisitas atau disebut residual tidak sama. Jika nilai sig pada uji Glejser untuk setiap variabel bebas $>0,05$ maka tidak terjadi heteroskedastisitas atau disebut varians residual yang sama.

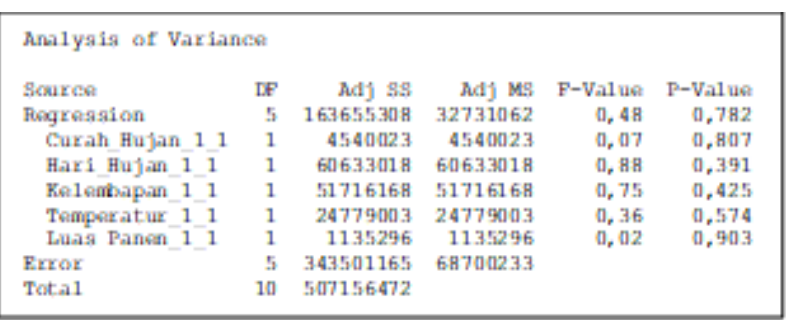

Figure 7. Hasil Uji Glejser

Berdasarkan hasil uji glejser diketahui bahwa nilai signifikansi (p-value) dari seluruh variabel bebas setelah direhresikan dengan absolute residual bernilai diatas 0,05 sehingga disimpulkan varians residual sama atau tidak terjadi heteroskedastisitas.

\subsection{Uji Kebaikan Model Regresi (Uji F)}

Kesesuaian atau kebaikan model regeresi dapat dilihat dari hasil analisa uji bersama/serentak atau uji simultan yang terdapat pada tabel Analysis of Variance pada Tabel 2.

Table 2. Hasil Analysis of Variance

\begin{tabular}{lllccc}
\hline Model & $\boldsymbol{d f}$ & Sum of square & Mean Square & F-hitung & P-value \\
\hline Regresi & 5 & 78946291619.472 & 15789258323.894 & 29,244 & 0,001 \\
Residual & 5 & 2699554742.576 & 539910948.515 & & \\
Total & 10 & 81645846362.047 & & & \\
\hline
\end{tabular}

Berdasarkan hasil uji serentak pada Tabel 3 menunjukkan bahwa bersarnya $P$ value sebesar 0,001 kurang dari kurang dari $0,05(\alpha: 5 \%)$, atau F-hitung senilai 29,244 lebih besar dari F tabel $(4,95)$ sehinga diputuskan tolak $\mathrm{H} 0$, hal ini berarti seluruh variabel independent secara simultan tidak berpengaruh signifikan terhadap produksi tembakau di Kabupaten Jember. Sehingga model atau persamaan regresi yang terbentuk dari analisis ini sudah sesuai dan memenuhi asumsi kebaikan model regresi.

\subsection{Uji Parsial}

Uji parsial digunakan untuk mengetahui pengaruh masing-masing variabel bebas secara parsial terhadap produksi tembakau di Kabupaten Jember. Hasil analisa uji parsial terlihat pada tabel 3 sebagai berikut: 
Table 3. Hasil Uji T

\begin{tabular}{llllll}
\hline Variabel & Koefisien & SE Koefisien & T-hitung & P-value & VIF \\
\hline (Constant) & 2456782,324 & 955577,457 & 2,571 & 0,050 & \\
Curah_Hujan & 0,890 & 0,268 & 3,324 & $\mathbf{0 , 0 2 1}$ & 1,79 \\
Hari_hujan & 0,120 & 0,168 & 0,717 & 0,505 & 1,54 \\
Kelembapan & $-16272,407$ & 4157,636 & $-3,914$ & $\mathbf{0 , 0 1 1}$ & 7,70 \\
Temperatur & $-49617,901$ & 25505,609 & $-1,945$ & 0,109 & 6,34 \\
Luas Lahan & 32,779 & 8,025 & 0,553 & $\mathbf{0 , 0 0 9}$ & 2,77 \\
\hline
\end{tabular}

Terlihat pada tabel 3 bahwa terdapat tiga variabel yang signifikan secara parsial. Hal ini ditunjukkan dari nilai $\mathrm{P}$ value yang kurang dari 0,05 , yaitu selain itu jika dibandingkan dengan nilai T.tabel statistik $( \pm 2,58)$, nilai t-value lebih besar dari T.tabel pada variabel curah hujan, kelembapan, dan luas lahan. Sehingga disimpulan terdapat variabel bebas yang secara parsial signifikan berpengaruh terhadap produksi tembakau di Kabupaten Jember.

\subsection{Model Regresi}

Berdasarkan hasil analisa regresi $\mathrm{R}^{2}$ sebesar 96,7\%, hal ini berarti kontribusi variabel bebas yakni curah hujan, hari hujan, kelembapan udara, temperatur, dan luas lahan tanam terhadap produksi tembakau di Kabupaten Jember sebesar $96,7 \%$ dan sisanya dipengaruhi faktor lainnya. Nilai $\mathrm{R}^{2}$ atau koefisien determinasi yang mendekati $100 \%$ menandakan bahwa model regresi yang dibangun sudah tepat dan dapat merepresentasikan keadaan sebenarnya. Model regresi yang terbentuk dari adalah sebagai berikut :

$$
Y=2456782,324+0,890 X 1+0,120 X 2-
$$$$
16.272,407 X 3-49617,901 X 4+32,779 \times 5
$$

Dimana :

Y : produksi tembakau (kwintal)

$\mathrm{X} 1$ : curah hujan per tahun $(\mathrm{mm} / \mathrm{thn})$

$\mathrm{X} 2$ : jumlah hari hujan per tahun

X3 : Kelembapan (\%)

$\mathrm{X} 4$ : Suhu udara $\left({ }^{\circ} \mathrm{C}\right)$

$\mathrm{X} 5$ : luas lahan yang ditanmai tembakau (hektar)

Model regresi tersebut menunjukkan bahwa konstanta atau intersep sebesar 2456782,324. Hal ini berarti jika seluruh variabel konstan atau nol, maka produksi tembakau yang dihasilkan sebesar 2456782,324 kwintal.
Kemudian koefisien regresi pada variabel curah hujan (X1) sebesar 0,890 yang berarti berpengaruh positif terhadap produksi tembakau. Hal ini dapat diasumsikan apabila curah hujan (X1) naik 1 satuan maka pertambahan produksi tembakau sebesar 0,890 kwintal dengan asumsi variabel independen lain konstan (cateris paribus). Kemudian koefisien regresi pada variabel jumlah hari hujan (X2) sebesar 0,120 yang berarti berpengaruh positif terhadap produksi tembakau. Hal ini dapat diasumsikan apabila jumlah hari hujan (X2) bertambah 1 satuan maka produksi tembakau bertambah sebesar 0,120 kwintal dengan asumsi variabel independen lain konstan (cateris paribus). Sedangkan koefisien regresi pada variabel kelembapan udara (X3) sebesar -16.272,407 yang berarti berpengaruh negative terhadap produksi tembakau. Hal ini dapat diasumsikan apabila kelembapan udara (X3) bertambah 1\% maka terjadi penurunan pada produksi tembakau sebesar 16.272,407 kwintal dengan asumsi variabel independen lain konstan (cateris paribus). Untuk koefisien regresi pada variabel suhu/temperature udara (X4) sebesar 49617,901 yang berarti berpengaruh negatif terhadap produksi tembakau. Hal ini dapat diasumsikan apabila suhu udara (X4) bertambah $1^{\circ} \mathrm{C}$ maka terjadi penurunan produksi tembakau sebesar 49.617,901 kwintal dengan asumsi variabel independen lain konstan (cateris paribus). Koefisien regresi variabel luas lahan tanam tembakau (X5) sebesar 32,779 yang berpengaruh positif terhadap produksi tembakau, hal ini terlihat ketika luas lahan tembakau naik satu hektar maka produksi tembakau naik sebesar 32,779 kwintal. 


\section{Conclusion}

Model matematis dari analisis pengaruh curah hujan, jumlah hari hujan, kelembapan, temperatur udara dan luas lahan terhadap produksi tembakau di Kabupaten Jember adalah sebagai berikut.

$$
\begin{aligned}
& Y=2456782,324+0,890 X 1+0,120 X 2- \\
& 16.272,407 X 3-49617,901 X 4+32,779 \times 5
\end{aligned}
$$

Dengan besar koefisien determinasi $96,7 \%$, hal ini menunjukkan pengaruh variabel curah hujan, jumlah hari hujan, kelembapan, temperatur udara dan luas lahan sebesar 96,7\% dalam mengakibatkan fluktuaasi peroduksi tembakau di Kabupaten Jember dan 3,3\% disebabkan oleh faktor lain.

\section{Acknowledgement}

Ucapan terimakasih kami sampaikan pada Politeknik Negeri Jember yang telah mendanai peneletian ini serta pihak Badan Pusat Statistik Kabupaten Jember yang telah bekerjasama dalam penyediaan data.

\section{References}

[1] Rachmawati, "Analisis Data Tembakau Jawa Timur 2018," Surabaya: PT Sinar Murni Indoprinting., 2018.

[2] H. Herminingsih, "Hubungan adaptasi petani terhadap perubahan iklim dengan produktivitas tembakau pada lahan sawah dan tegalan di kabupaten jember," J. Sos. Ekon. Pertan., vol. 7, no. 2, p. 22636, 2014.

[3] Direktorat Jendral Perkebunan, "Statistik Perkebunan Indonesia 2018-2020.,” 2020.

[4] W. KUSUMANDARU, "Analisis indeks kualitas tanah di lahan pertanian tembakau kasturi berdasarkan sifat kimianya dan hubungannya dengan produktivitas tembakau kasturi di Kabupaten Jember," 2015.

[5] E. S. Hani, S. Soetriono, and H. Paramu, "Pemodelan dan Strategi Competitiveness Agribisnis Tembakau Besuki Na-Oogst di Jawa Timur," JSEP (Journal Soc. Agric. Econ., vol. 3, no. 2, pp. 59-69, 2009.

[6] J. A. Arifandi, A. Wardhono, and Y. Indrawati, Panduan Praktik Budidaya Tembakau Besuki NaOogst. Pustaka Abadi, 2018.

[7] R. T. Muktianto and H. C. Diartho, "Komoditas tembakau besuki Na-Oogst dalam perspektif pembangunan berkelanjutan Di Kabupaten Jember,"
Caraka Tani J. Sustain. Agric., vol. 33, no. 2, pp. 115$125,2018$.

[8] L. Verona and D. Djajadi, "KERAGAAN USAHATANI TEMBAKAU KASTURI (Studi Kasus Usahatani Tembakau Kasturi di Kabupaten Jember)," Agrika, vol. 14, no. 1, pp. 70-80, 2020.

[9] N. Herlina, N. Azizah, and E. P. Pradiga, "Pengaruh Suhu dan Curah Hujan terhadap Produktivitas Tembakau (Nicotiana tabacum L.) di Kabupaten Malang," PLANTROPICA J. Agric. Sci., vol. 5, no. 1, pp. 52-63, 2020.

[10] M. Sholeh, "Keterkaitan Antara Kondisi Iklim dan Perencanaan Tanam Tembakau Virgnia.," pp. 53-63, 2012.

[11] D. P. Ariyono, “ANALISIS PENDAPATAN USAHATANI TEMBAKAU DI DESA BANJARDOWO KECAMATAN KABUH KABUPATEN JOMBANG." University of Muhammadiyah Malang, 2018.

[12] D. W. Widiastuti, "Faktor-faktor yang Mempengaruhi Produksi Tembakau Besuki NaOogst Di Desa Jambe Arum Kecamatan Puger Kabupaten Jember."

[13] Soetriono, Evita Solihahani, F. Zulan Anisa, N. Inayatin, N. Susanti, and Q. Zuniana, Agribisnis Tembakau Besuki Na- Oogst : 2014.

[14] M. Sholeh, "Keterkaitan antara Kondisi Iklim dan Perencanaan Tanam Tembakau Virginia," Balai Penelit. Tanam. Tembakau dan Serat, Malang, 2012.

[15] S. Sudaryono, "Pengaruh naungan terhadap perubahan iklim mikro pada budidaya tanaman tembakau rakyat,” J. Teknol. Lingkung., vol. 5, no. 1, 2004.

[16] H. Herminingsih, R. Agribisnis, F. U. Jember, and K. No, "Pengaruh perubahan iklim terhadap perilaku petani tembakau di kabupaten jember," J. Mat. Saint, Teknol., vol. 5, no. 2, pp. 42-51, 2014.

[17] D. P. Sugiyono, "Statistika untuk Penelitian (28th editi)," Bandung Alf., 2017.

[18] A. P. D. R. Irianto, "Statistik konsep dasar \& aplikasinya," 2004.

[19] D. N. Gujarati, “Ekonometrika dasar,” 2016.

[20] N. R. Drapper and H. Smith, "Analisis Regresi Terapan (Edisi Kedua)," Alih Bhs. oleh PT. Gramedia Pustaka Utama. Jakarta, 1992.

[21] [21] I. Ghozali, "Aplikasi Analisis Multivariate degan Program SPSS. Cetakan Keempat, Badan Penerbit Universitas Diponegoro, Semarang. Empirical Evidence on Canadians Firms. School of Accounting University of Central Florida." 2013. 